\title{
The Effect of Produced Water from Heglig Oil Field on Chemical Additives for Fracturing Fluids
}

\section{Fatima A Elbrir}

Department of Petroleum Engineering, College of Petroleum Engineering and Technology, Sudan University of Science and Technology, Khartoum-Sudan

*Corresponding author: Fatima A Elbrir, Department of Petroleum Engineering, College of Petroleum Engineering and Technology, Sudan University of Science and Technology, Khartoum-Sudan, Tel: +249(0)122924771; E-mail: fatimawael12@hotmail.com

Received date: March 26, 2018; Accepted date: April 10, 2018; Published date: April 19, 2018

Copyright: (C) 2018 Elbrir FA, et al. This is an open-access article distributed under the terms of the Creative Commons Attribution License, which permits unrestricted use, distribution, and reproduction in any medium, provided the original author and source are credited.

\begin{abstract}
Produced water is the water produced with oil or gas during well production as a result of different operations. Recently, many Sudanese oil fields suffer from the massive amount of water production; the most water production problems in Sudan were observed in Heglig oilfield. The Heglig oilfield is located in Muglad Basin in the southeast and middle of Block 2 in Sudan. The oil production from Heglig oilfield was reported to have peaked in 2006, however it has been declined now and the water cut was reached 95\%. Due to many environmental impacts, several studies were conducted for treating the produced water from Heglig oilfield to be used in irrigation; no work was presented to study the effect of Heglig oilfield produced water on chemical additives for fracturing fluids. However, this work analyzes and treats the produced water from Heglig oilfield and evaluates the possibility of the treated water for the re-using in water base fracturing fluids. Samples were collected from two different ponds in the field and analysed according to the American Public Health Association (APHA) and the results were compared with (National Recommended Water Quality (EPA)) to identify the required treatments for the collected water. The analysis was done in Rheine Waal University of Applied Science-Kamp-Lint fort-Germany.
\end{abstract}

In this study, the effect of produced water from Heglig oil field on fluid formulation was studied as management processes of produced water prior to reuse for petroleum operation (Hydraulic Fracturing and Injection) or to be safe in environment. The $\mathrm{pH}$ effect on fluids viscosity was investigated for $(6,7,8,9$ and 10$)$. The results showed that the cross-linking ability of the fracturing fluid presented that better cross-linking system were achieved with $0.48 \mathrm{~g}$ CMHEC at $\mathrm{pH}$ of 8 and temperature of $40^{\circ} \mathrm{C}$ for $\mathrm{HEC}$ and $60^{\circ} \mathrm{C} \mathrm{CMHEC}$.

Keywords: Produced water; Fracturing fluids; Cross-linking system

\section{Abbreviations:}

HEC: Hydroxyethyl Cellulose; CMHEC: Carboxymethyl Hydroxyethyl Cellulose; TSS: Total Suspended Solid; TDS: Total Dissolved Solids.

\section{Introduction}

Produced water is the natural water or formation water is always found together with petroleum in reservoirs [1]. Other definition of "Produced water" is water trapped during subsurface formations which is brought to the surface along with oil or gas [2]. Sometime called "flowback water" if it is brought from fluid injected into the well or reservoir at high pressure as part of a hydraulic fracturing (frac) operation [3]. It is slightly acidic and sits below the hydrocarbons in porous reservoir media extraction of oil and gas leads to a reduction in reservoir pressure, and additional water is reservoir water layer to maintain hydraulic pressure and enhance oil recovery. Produced water has a complex composition, but its constituents can be broadly classified into organic and inorganic compounds [2-5] including dissolved and dispersed oils, grease, heavy metals, radionuclides, treating chemicals, formation solids, salts, dissolved gases (including $\mathrm{CO}_{2}$ and $\mathrm{H}_{2} \mathrm{~S}$ ), scale products, waxes, microorganisms and dissolved oxygen[5-8]. Cations and anions play a significant role in the chemistry of produced water [9]. Produced solids could cause serious problems during oil production. For example, common scales and bacteria can clog flow lines, form oily sludge and emulsions which must be removed [10]. For Heglig Oilfield, as case study the amount of water production or water cut reach to $95 \%$ from total hydrocarbon fluids, making oil production non-economic. Therefore, the objective of this paper is to study the effect of produced water from Heglig oil field on chemical additives for fracturing fluids. Scale deposition is one of the most important and serious problems that inflict oil field water injection systems. Scale limits and sometimes blocks oil and gas production by plugging the oil producing formation matrix or fractures and perforated intervals. It can also plug production lines and equipment and impair fluid flow.

\section{Field background}

Heglig oil field is one of the largest fields of oil and gas deposits in Sudan. It has been the site of conventional petroleum production for more than one decade (since 1999), but recently it has become producing water exceed the economic range (Figures 1 and 2). Heglig field is located in southeast and middle of Block 2B, Muglad Basin, discovered by Chevron. It consists of 10 fields (Heglig main, Toma, El Bakh, El Full, Laloba, Kanga, Barki, Hamra, Simbir East and Rihan). A general structure which follows average distance between fields is about 3 to $5 \mathrm{~km}$. 8 layers are developed i.e., Aradeiba main, Aradeiba B, Aradeiba E, Aradeiba F, Bentiu-1, Bentiu-2 and Bentiu-3 and Abu Gabra. First FDP was carried out in 1998. Last FDP was carried out in 2011. Field development started in June 1999 with development of 29 
Citation: Elbrir FA (2018) The Effect of Produced Water from Heglig Oil Field on Chemical Additives for Fracturing Fluids. J Environ Anal Chem

Page 2 of 6

wells i.e., Heglig main (17), Toma (4), Barki (3) , Hamra (2), El FulI (2) wells and El Bakh (1) well.

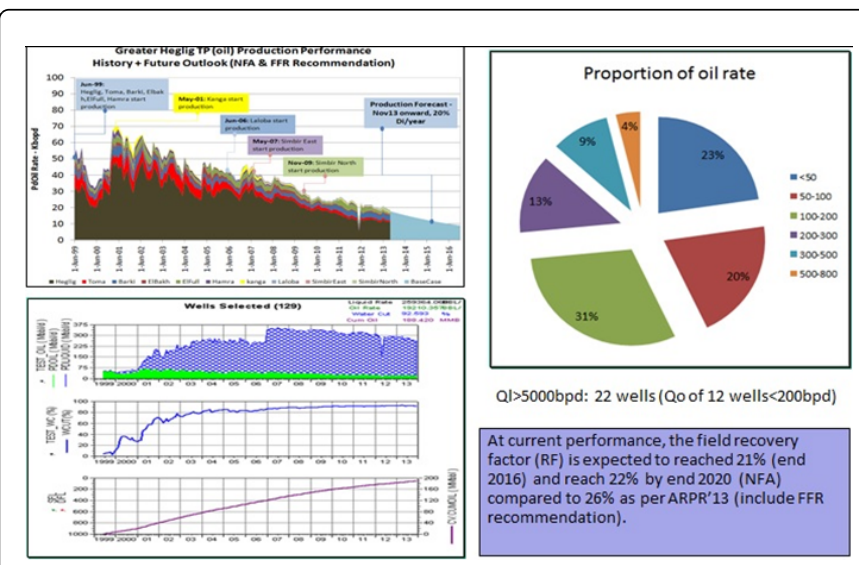

Figure 1: Heglig field background - production performance.

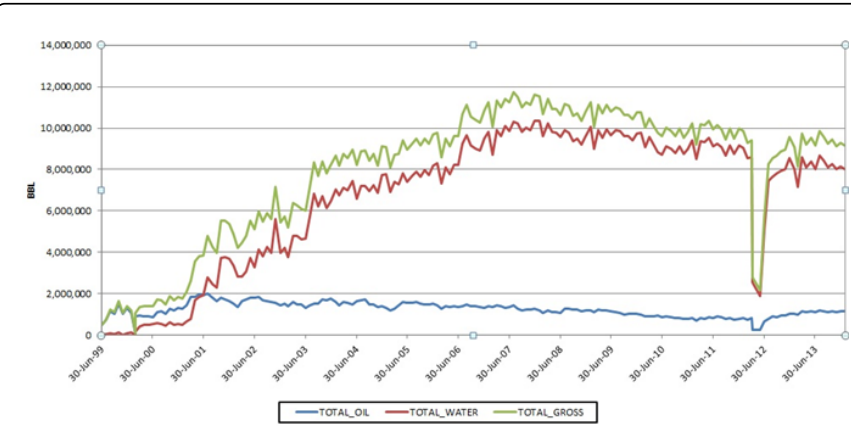

Figure 2: Total water production from 1999 up to 2013.

\section{Experimental work}

\section{Produced water from Heglig oil field}

Sample collection: Produced water samples were obtained from the Heglig oil field (Table 1). Sample has been taken from two different ponds; the first pond presents the untreated water, while the second pond presents the water after the final field treatments with bioremediation project. Samples were taken using sterile bucket and stored in sterile containers of different sizes ( $1 \mathrm{~L}$ and $1 / 2 \mathrm{~L}$ ) and has been kept in $4^{\circ} \mathrm{C}$. This water have been experimentally measured before treatment in order to define its components such as Total Suspended Solids (TSS), Total Dissolved Solids (TDS), oil and grease, bacteria and metals. The characterization has been done using methods of testing available in Sudan and Germany in order to evaluate the compatibility of proposed treated water with hydraulic fracturing additives and formation water, in order to eliminate any problems that may cause by incompatibility.

\begin{tabular}{|c|c|c|c|c|}
\hline Parameters & Raw water $(\mathrm{mg} / \mathrm{l})$ & Treated water (mg/l) & Acceptable range $(\mathrm{mg} / \mathrm{l})$ & Comments \\
\hline $\mathrm{pH}$ & $8.9-9.5$ & $8.3-8.6$ & $6-8$ & Hydration \\
\hline Oil and grease & $250-300$ & $30-50$ & Zero & Fluid stability \\
\hline Total Dissolved Solids (TDS) & 2662 & 3217 & 300 & Hydration \\
\hline Total Suspended Solids (TSS) & 982 & 378 & Zero & Well plugging \\
\hline Conductivity $(\mu \mathrm{mhos} / \mathrm{cm})$ & 2.7 & 3.2 & - & - \\
\hline Chloride & 20 & 14 & $<2-00$ & Fluid stability \\
\hline Sodium & 575 & 678 & Zero & Scaling \\
\hline Silica & 11.8 & 11.8 & $<1$ & Crossling \\
\hline Potassium & 12.77 & 14.03 & Zero & Scaling \\
\hline Calcium & 7.193 & 8.19 & Zero & Scaling \\
\hline \multicolumn{5}{|l|}{ Heavy Metals (ppm) } \\
\hline Aluminium (Al) & 21.6 & 0.2871 & - & - \\
\hline Cadmium (Cd) & $<0.0009$ & $<0.0009$ & - & - \\
\hline
\end{tabular}


Page 3 of 6

\begin{tabular}{|c|c|c|c|c|}
\hline Chromium (Cr) & 0.0158 & $<0.0013$ & - & - \\
\hline Copper (Cu) & 0.0249 & 0.0249 & - & - \\
\hline Cobalt (Co) & 0.0013 & 0.0013 & - & - \\
\hline Iron $(\mathrm{Fe})$ & 12.17 & 12.17 & Zero & Crossling/hydration \\
\hline Lead $(\mathrm{Pb})$ & $<0.0150$ & $<0.0150$ & - & - \\
\hline Manganese (Mn) & 0.1052 & 0.0049 & - & - \\
\hline Nickel (Ni) & 0.0155 & 0.0127 & - & - \\
\hline Zinc (Zn) & 0.066 & 0.0474 & - & - \\
\hline Boron $(\mathrm{Br})$ & 0.01 & 0.01 & Zero & Scaling \\
\hline Mercury $(\mathrm{Hg})$ & ND & ND & - & - \\
\hline Phosphorus & $<0.001$ & ND & - & - \\
\hline Cadmium (Cd) & ND & ND & - & - \\
\hline
\end{tabular}

Table 1: Physical and chemical properties of water sample.

\section{Water sampling preparation}

The following tests were conducted to determine the main components and their proportion that could be found.

Total Suspended Solids measurement (TSS): A volume of produced water was measured according to APHA standard methods. Filter was carefully removed using filtration apparatus and transferred to an Aluminium weighing dish in order to reduce high dissolved solids. It was then dried for $1 \mathrm{~h}$ at $103^{\circ} \mathrm{C}$ to $105^{\circ} \mathrm{C}$ in an oven, cooled in desiccator to balance temperature and weighed and the TSS content was calculated in $\mathrm{ppm}(\mathrm{mg} / \mathrm{l})$ as:

Total Suspended Solids $($ TSS $)=a-b \times 1000 /$ sample volume $(\mathrm{ml})(1)$

Total Dissolved Solids measurement (TDS): TDS solids and electric conductivity was measured using conductivity meter (Jenway 4320), 50 $\mathrm{ml}$ for two samples were used.

Oil and grease measurement: Oil and grease was extracted following APHA standard methods. A measured volume of the sample $(\mathrm{V}=250$ $\mathrm{ml}$ ) was introduced into separating funnel and $1.5 \mathrm{ml}$ of $\mathrm{HCl} 1: 1$ was added. $7.5 \mathrm{ml}$ of $\mathrm{n}$-Hexane was added to the acidified sample and shaken for $2 \mathrm{~min}$. When it reached the equilibrium the organic layer of oil and hexane was separated in evaporating dish. Then this step was replicated 2 times more and all the separated organic layer was transferred into a pre-weighed (W1 (gm)) flask and hexane was evaporated in a water bath at $103^{\circ} \mathrm{C}$ to $105^{\circ} \mathrm{C}$ for $1 \mathrm{~h}$. The flask is reweighed (W2 (gm)) and the oil and grease content is calculated in $\mathrm{ppm}(\mathrm{mg} / \mathrm{l})$ as:

a-b/sample volume $(\mathrm{ml}) \times 106(2)$

\section{Preparation of hydraulic fracturing fluid with HEC and CMHEC}

During the fracturing fluids process, a viscous non Newtonian fluid was applied to the formation with three major functions:

Delivering pressure to create fracture network and geometry within simulated zone.
Transporting proppant into the created fracture to maintain fracture conductivity.

Control of fluid leak off into the formation by forming a filter cake on the walls of the fracture.

Fracturing fluid was prepared by blending a hydratable polymer into an aqueous fluid. The aqueous fluid could be distilled water, untreated produced water, treated produced water (by process conducted in site of the Heglig oil field). In the case of batch mixing, the hydratable polymer and the aqueous fluid are blended for a period of time sufficient to form a hydrated solution.

Two types of hydratable polymers useful in the present study of cellulose derivatives Hydroxyethyl Cellulose (HEC) and Carboxymethyl Hydroxyethyl Cellulose (CMHEC), may be all of the hydratable were used and are well known to those in the well service industry.

\section{Rheological properties and testing}

Out of a hydration study, polymer powder was added to $100 \mathrm{ml}$ of different types of water with stirring in a Waring ${ }^{\oplus}$ blender (medium rate that was enough to generate a slight vortex) to make up the desired concentration. According to Vo [11], the following series tests were conducted.

In the first test, the aqueous solution contained HEC was prepared by adding different concentration of powder ranged from 2.5 to 5 gram per $100 \mathrm{ml}$ of tap water in order to obtain stock solution. A solution containing buffer for adjusting $\mathrm{pH}$, the quantity of polymer was hydrated (starrier) in $1 \mathrm{~L}$ of untreated produced water for about 30 min. The solution was divided into $200 \mathrm{ml}$ aliquots in beaker glasses. Aliquots were mixed with a speed of $1500 \mathrm{rpm}$ to get vortex. The samples were placed into constant temperature and the viscosities measured by proRheo R 180 rheometer with concentric cylinder.

In the second series of the tests, the same polymer concentrations in the first series were used. The aqueous solution was prepared according to same procedure described in the first series. The tests were 
conducted at different temperatures ranged from 10 to $80^{\circ} \mathrm{C}$ with aqueous solutions which were thickened with 2.5-5 g of HEC cellulose per $100 \mathrm{ml}$ of solution. Viscosities were determined with a proRheo $\mathrm{R}$ 180 rheometer.

In the third series of the tests, the effect of various $\mathrm{pH}$ on the viscosity of an aqueous solution thickened with two types of cellulose per $100 \mathrm{ml}$ of solution was tested and the procedures were repeated.

Lastly, in fourth series of the tests, the effect of shear rates on the viscosity was investigated. All the above procedures were used for both the types of polymer.

\section{Viscosity of fracturing fluids}

Viscosity was measured several times to show continuous loss of viscosity with time at simulated down hole temperature range from 10 to $80^{\circ} \mathrm{C}$ and constant shear rates $300 \mathrm{sec}^{-1}$ and several time with different $\mathrm{pH}$ and constant shear rates and sometimes with different shear rates.

The viscosity of the fracture fluids is very important. The fluid should be viscous enough (normally 50-1000 cp) to create a wide fracture (normally $0.2-1.0 \mathrm{in}$ ) and transport the propping agent into the fracture (normally $10 \mathrm{~s}$ to $100 \mathrm{~s}$ of feet) (Department of Energy, 2004).

\section{Cross-linking system of the polymer}

The cross-linking system of the present study for water based well fracturing fluids comprises of a mixture of Aluminium ion constituent with a Boron constituent. The boron constituent was selected from the group consisting Sodium tetraborate and mixtures thereof.

The liquid cross-linking system was prepared by first dissolving the Boron constituent. Aluminium ions are then added and mixed thoroughly. A water based fracturing fluid can be prepared which comprises of water, the cross-linking system described and a hydratable polymer capable of gelling in the presence of cross-linking system. The hydratable polymer useful in the present study can be any hydratable cellulose derivatives CMHEC and HEC. The water based fracturing fluid can be prepared for use by adding three types of water such as deionized water, raw water and treated water in site of the field. Borate cross-linked was used $(0.5-2.0 \%)$ by weight of polymer according to Patent (US5806597).

The water based fracturing fluid prepared contained about 5 to $7 \mathrm{~g}$ of hydratable polymer per $100 \mathrm{ml}$ of water used for HEC cellulose derivative and most $0.48 \mathrm{~g}$ per $100 \mathrm{ml}$ of water for CMHEC cellulose derivative.

\section{Results and Discussion}

\section{Fracturing fluid rheology at different conditions}

The fracturing fluid was formulated with oilfield produced water before and after treatment. The rheological properties of fracturing fluid tested are evaluated at various expected treating temperatures, shear rates and $\mathrm{pH}$. A viscosity performance of cross linked-HEC, CMHEC designed with typical oilfield produced formation water at temperature range of 10 to $80^{\circ} \mathrm{C}$ and shear rates range of 300 to 1000 $\mathrm{sec}^{-1}$ the results are reported as follows (Figures 3-11).

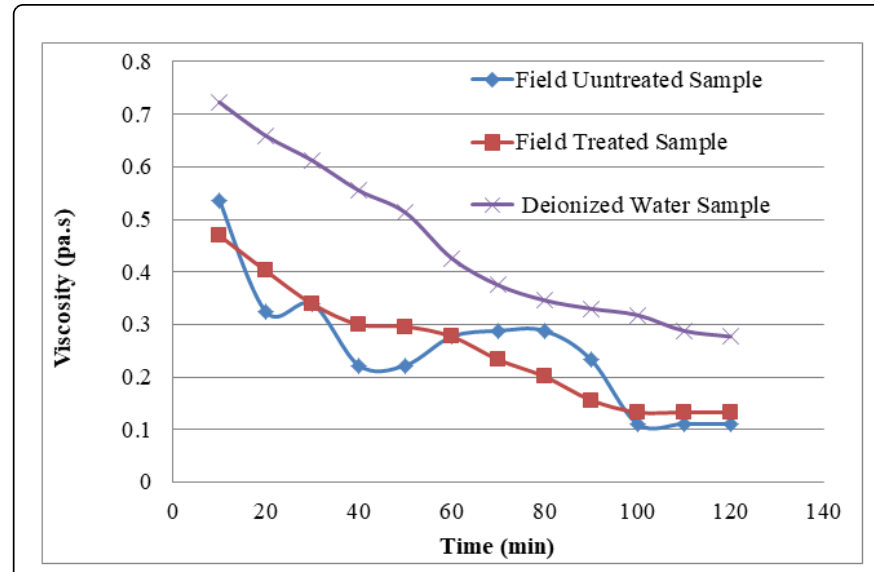

Figure 3: Rheology studies of $5 \mathrm{~g}$ HEC using three samples of water $(\mathrm{pH}=7.2)$, ambient temperature and $300 \mathrm{sec}^{-1}$.

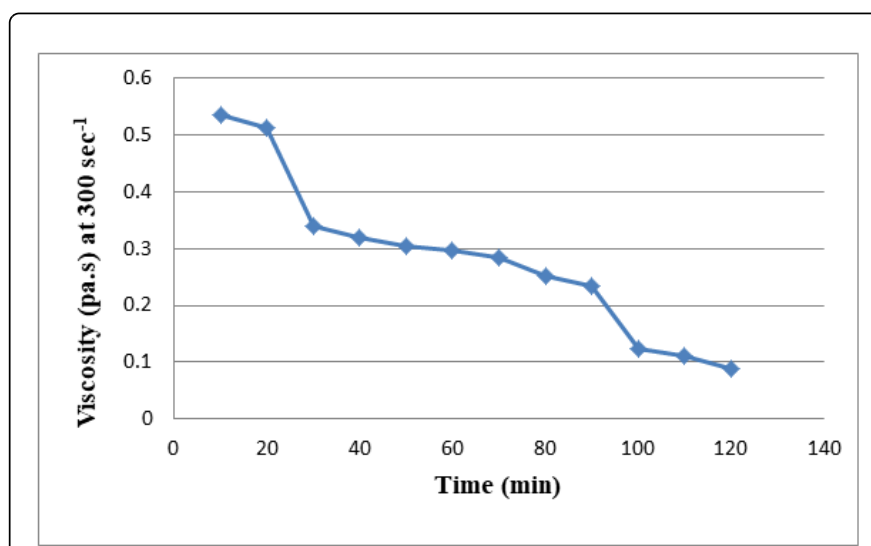

Figure 4: Rheology study of HEC at ambient temperature and 300 $\sec ^{-1} 100 \%$ untreated formation water $\mathrm{pH}=8.5$.

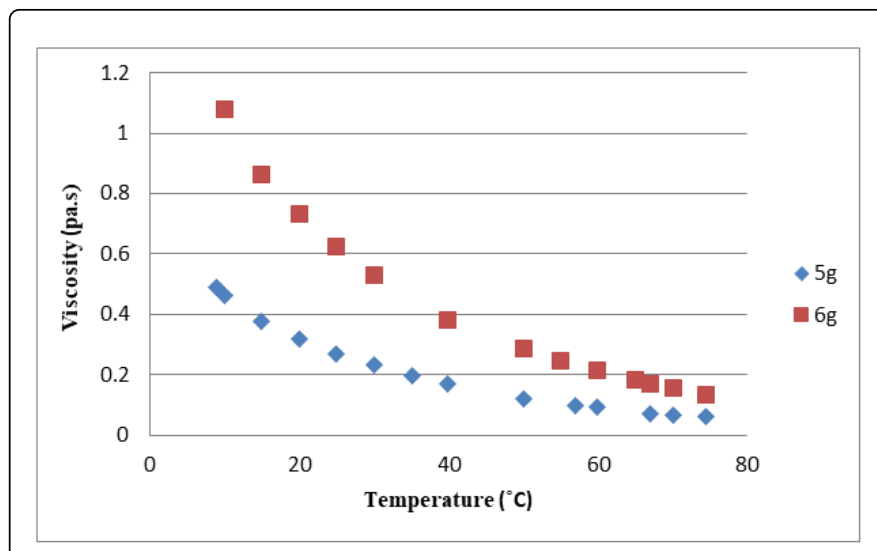

Figure 5: HEC viscosity at different temperature without crosslinker. 
Citation: Elbrir FA (2018) The Effect of Produced Water from Heglig Oil Field on Chemical Additives for Fracturing Fluids. J Environ Anal Chem

Page 5 of 6

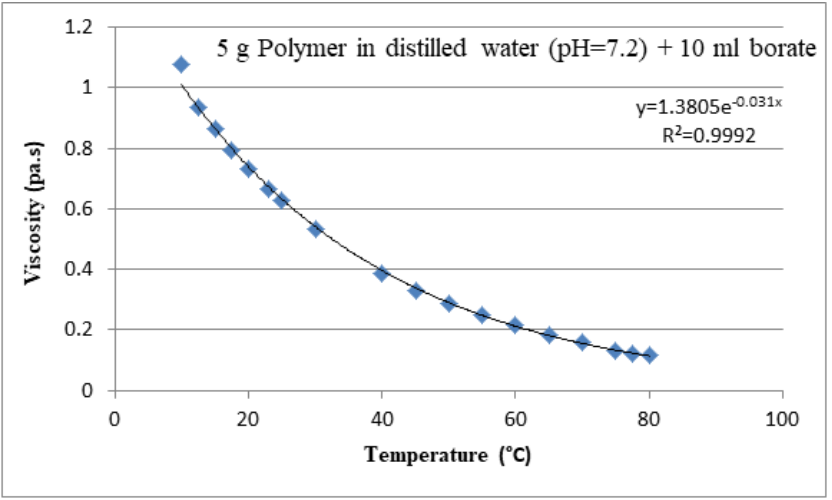

Figure 6: The effect of cross-linker on HEC at different temperature.

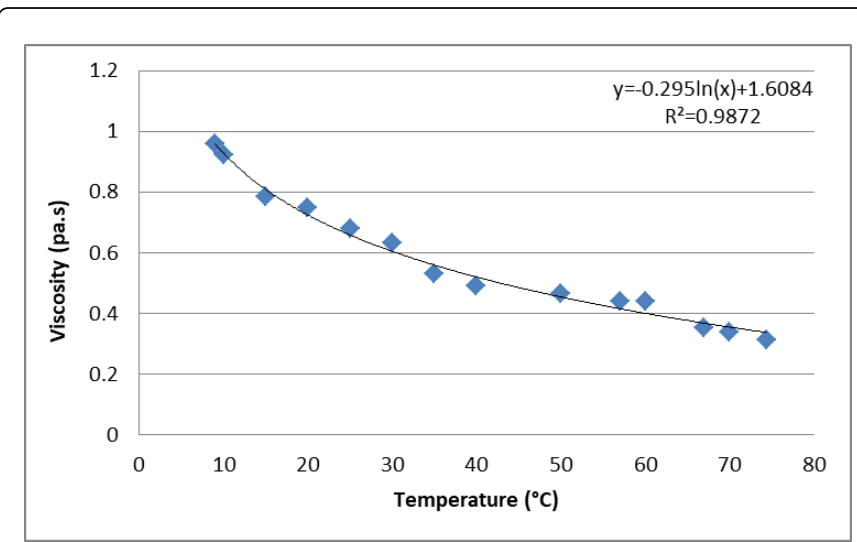

Figure 7: The effect of cross-linker on CMHEC at different temperature using treated water.

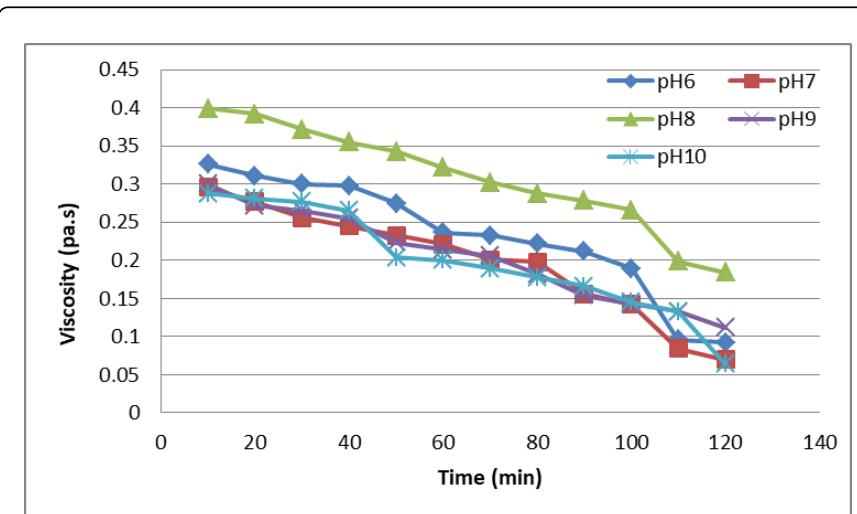

Figure 8: Rheology study of HEC at ambient temperature and 300 $\sec ^{-1} 100 \%$ untreated water.

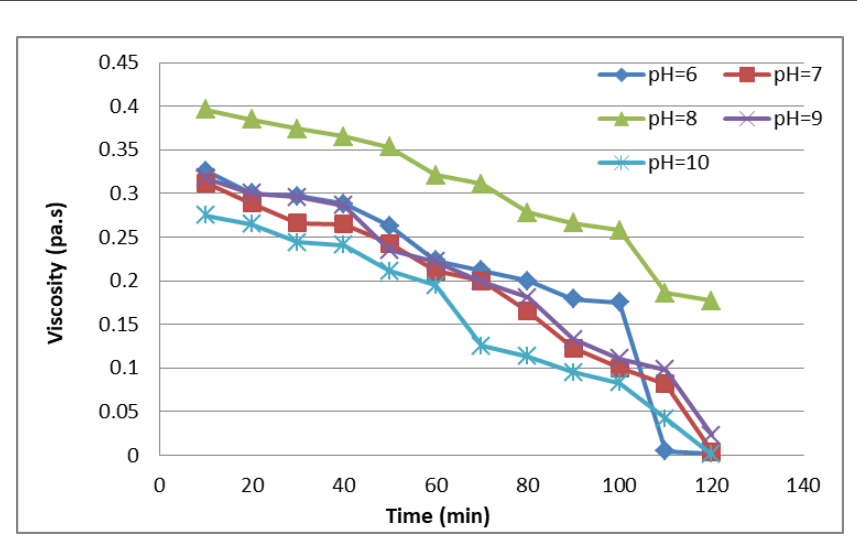

Figure 9: Rheology study of HEC at ambient temperature and 300 $\sec ^{-1} 100 \%$ treated water (on site the field).

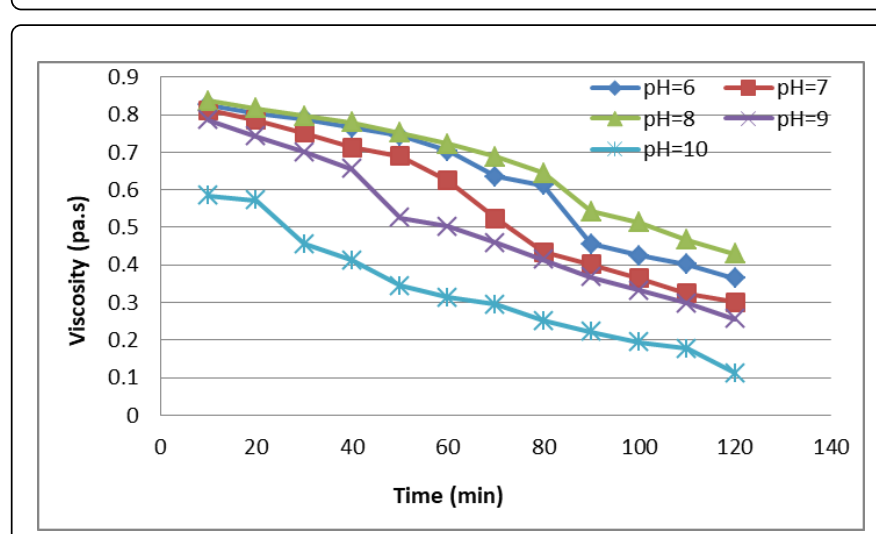

Figure 10: Rheology study of cross-linked CMHEC at ambient temperature and $300 \mathrm{sec}^{-1} 100 \%$ untreated water.

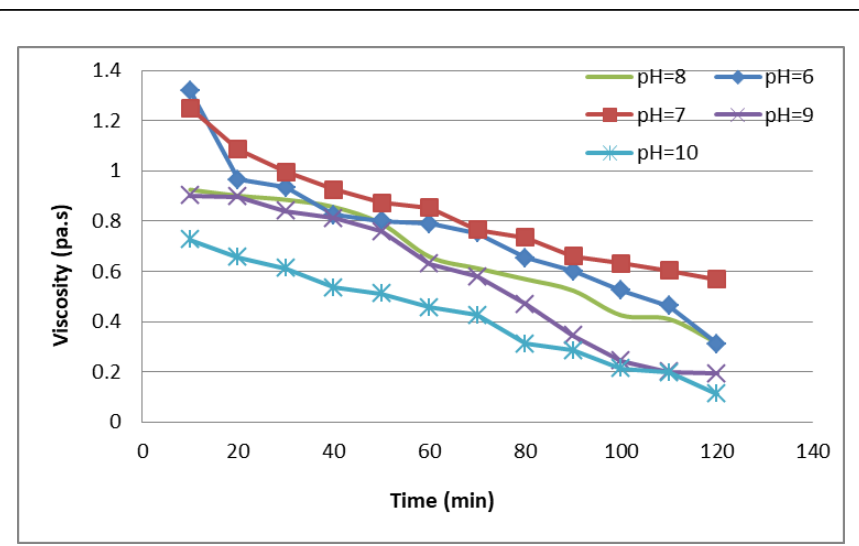

Figure 11: Rheology study of cross-linked CMHEC at ambient temperature and $300 \mathrm{sec}^{-1} 100 \%$ treated water (on site of the field).

\section{Conclusion}

In this study, fracturing fluids formulation with three types of water was prepared. Borate and Aluminium ion with cellulose derivatives 
Citation: Elbrir FA (2018) The Effect of Produced Water from Heglig Oil Field on Chemical Additives for Fracturing Fluids. J Environ Anal Chem 5: 237. doi:10.4172/2380-2391.1000237

Page 6 of 6

(HEC and CMHEC) in aqueous solution were investigated by using rheological measurements. The evolution of viscoelastic properties of the borate solutions and the Ammonium ion mixtures separately were characterized and the cross-linking kinetics was determined. The results indicate that the development of the cross-linking network is highly dependent on the borate concentration while the cellulose derivatives concentration is relatively unimportant. The effects of $\mathrm{pH}$, temperature, shear rates and cellulose derivatives dosage on fluids formulation were systematically investigated. Optimal reaction conditions for formulation were obtained $(\mathrm{pH}: 6$ and 8; temperature: $>80^{\circ} \mathrm{C} ; 5$ g polymer dosage).

\section{Acknowledgement}

The authors would like to thank the organization of German Academic Exchange Service (DAAD) for financial assistance (Internal scholarship) at the Rheine Waal University of Applied Science (Germany) for its technical support.

\section{References}

1. Almond SW, Bland WE, Ripley HE (1984) The Effect of Break Mechanisms on Gelling Agent Residue and Flow Impairment in 20/40 Mesh Sand. Petroleum Society of Canada. In Annual Technical Meeting.
2. American Petroleum Institute (2010) Water Management Associated with Hydraulic Fracturing. API Guidance Document, HF2.

3. Anon (1998) Stable breaker-crosslinker-polymer complex and method of use in completion and stimulation.

4. Arthur J, Langhus B, Patel C (2005) Technical Summary of Oil \& Gas Produced Water Treatment Technologies. ALL Consulting, LLC, Tulsa, Oklahoma, USA, pp. 1-53.

5. Aqualon (2007) Guar and Guar Derivatives Oil and Gas Field Applications.

6. Bankole KS, Blauch M (2014) Applications of Oilfield Produced Formation Water for Fracturing Fluid. Research Journal of Applied Sciences, Engineering and Technology 7: 2208-2216.

7. Bybee K (2005) Oil/Water-Separation Experience from a Large Oil Field. Journal of Petroleum Technology 57: 41-42.

8. Bybee K (2011) Produced-Water-Volume Estimates and Management Practices. Journal of Petroleum Technology 63: 77-79.

9. Department of Energy, U.S., 2004. EPA 816-R-04-003 Appendix A Hydraulic Fracturing White Paper. pp. 23.

10. Graham EJS, Bowman RS, Katz L, Kinney KA (2004) Water treatment technology for oil and gas produced water. Identifying Technologies to Improve Regional Water Stewardship, pp. 216-225.

11. Vo LK, Sparks B, Parton C, Cortez J, Green T (2014) Novel Low-Residue High Brine Fracturing Fluid. American Association of Drilling Engineers, pp. 1-7. 